\title{
ETHNIC DIFFERENCES IN THE INCIDENCE OF MALFORMATIONS FOLLOWING MIGRATION*
}

\author{
BY \\ IAN LECK, M.B., Ph.D. \\ Medical Unit, University College Hospital Medical School, London, and the Department of Social Medicine, \\ University of Birmingham
}

Most malformations are of unknown cause. Many types tend to recur in families and also vary in incidence according to circumstances such as season and year of conception and parental social class, age, parity, and ethnic origin; but it is uncertain whether these variations are predominantly genetic or environmental in origin, since most of the groups compared differ in both these respects.

The influence of ethnic origin on incidence seems to be especially profound (Neel, 1958); and in recent years the arrival in Britain of many members of non-indigenous ethnic groups has opened up the possibility of clarifying the relative importance of genotype and environment by studying their offspring. For many generations, the incidence of genetically determined malformations might be expected to remain almost the same as in the country of origin. The pattern of environmentally determined defects, on the other hand, would probably become more like that observed in children of indigenous descent, although this change might not be immediate if cultural factors were responsible for the difference.

In this paper, the main immigrant groups in Birmingham are compared with those of similar ethnic origin in other countries, and with the British-born population, in respect of the incidence of malformations among their offspring. Figures for children of mixed parentage are also given; there were not sufficient of the latter to indicate clearly how such children compare with their parental ethnic groups in respect of malformations, but it is felt that all figures of this kind should be placed on record until there are enough to support the use of such comparisons in aetiological studies.

\section{MATERIAL}

Demographic and medical data relating to all births to Birmingham residents have been recorded

This work was assisted by a grant from the Association for the Aid of Crippled Children, New York. on punch cards in the municipal Health Department since 1949 (Charles, 1951), and since 1950 additional cards in respect of malformed children, including particulars of their defects, have been punched in the Department of Social Medicine at Birmingham University (Edwards, Leck, and Record, 1964; Leck, Record, McKeown and Edwards, 1968).

The present communication deals with births in 1960-65. In most of these cases, information regarding the ethnic origins of both parents and the social class of the father or other person providing for the child was recorded by the city's health visitors, except that for children who were stillborn or who died without a health visitor seeing them this recording was done by the midwives and maternity hospital staff.

The sources from which malformations were ascertained in 1960-65 were (i) health visitors' records; (ii) lists of admissions to local hospitals; and (iii) Health Department records of the birth histories, causes of death and necropsy findings for stillbirths and dead children, supplemented by original necropsy reports in a few cases where the other records were insufficiently precise. We have shown elsewhere (Leck and Millar, 1963; Leck, 1964) that these methods appear to be adequate for the ascertainment of neural tube defects, oral clefts, oesophageal and anal atresias, bilateral renal agenesis, limb deficiencies, non-hiatal diaphragmatic hernia, and exomphalos. This communication deals only with these types of defects, and with Down's disease. Children with the latter condition (including those classed as ineducable or educationally subnormal or on the At Risk register, as well as those ascertained from the other sources) are included because their particulars were available from a previous study (Leck, 1966).

\section{RESULTS}

According to our records, 133,539 children (including stillbirths) were born to Birmingham residents in 1960-65, and 1,201 had defects of the 
TABLE I

ETHNIC DISTRIBUTION OF BIRTHS TO BIRMINGHAM RESIDENTS 1960-65

\begin{tabular}{|c|c|c|c|c|}
\hline \multirow{2}{*}{ Parental Origin } & \multicolumn{2}{|c|}{ All Years } & \multicolumn{2}{|c|}{ 1963-65 only } \\
\hline & Total & Malformed & Total & Malformed \\
\hline $\begin{array}{l}\text { British } \\
\text { Irish } \\
\text { British Mother } \times \text { Irish Father } \\
\text { Irish Mother } \times \text { British Father } \\
\text { Other European } \\
\text { Total European }\end{array}$ & $\bar{E} \bar{z}$ & $\begin{array}{l}\bar{z} \\
\bar{z} \\
1,019\end{array}$ & $\begin{array}{r}42,515 \\
6,880 \\
2,719 \\
1,196 \\
1,140 \\
54,510\end{array}$ & $\begin{array}{r}351 \\
75 \\
22 \\
9 \\
9 \\
466\end{array}$ \\
\hline West Indian & 12,756 & 48 & 7,000 & 22 \\
\hline $\begin{array}{l}\text { European Mother } \times \text { West Indian Father } \\
\text { West Indian Mother } \times \text { European Father } \\
\text { Total European } \times \text { West Indian }\end{array}$ & $\overline{\overline{1}} \overline{528}$ & - & $\begin{array}{r}760 \\
24 \\
784\end{array}$ & $\begin{array}{l}\mathbf{3} \\
\mathbf{0} \\
\mathbf{3}\end{array}$ \\
\hline Indian or Pakistani & 3,132 & 29 & 2,243 & 20 \\
\hline $\begin{array}{l}\text { European Mother } \times \text { Indian/Pakistani Father } \\
\text { Indian/Pakistani Mother } \times \text { European Father } \\
\text { Total European } \times \text { Indian/Pakistani }\end{array}$ & $\overline{\overline{9}}$ & $\overline{-}_{6}$ & $\begin{array}{r}494 \\
24 \\
518\end{array}$ & $\begin{array}{l}4 \\
0 \\
4\end{array}$ \\
\hline Other recorded & 1,261 & 4 & 926 & 3 \\
\hline $\begin{array}{l}\text { Mother alone recorded } \\
\text { Father alone recorded } \\
\text { Neither parent recorded } \\
\text { Total not recorded }\end{array}$ & $\bar{z}$ & $\bar{z}$ & $\begin{array}{r}608 \\
9 \\
967 \\
1,584 \\
\end{array}$ & $\begin{array}{r}15 \\
0 \\
36 \\
51\end{array}$ \\
\hline Total & 133,539 & 1,201 & 67,565 & 569 \\
\hline
\end{tabular}

TABLE II

RECORDING OF ETHNIC ORIGIN 1960-65



types considered. Table I shows how the affected children and the related population were distributed in respect of ethnic group. Separate figures are given for births in 1963-65 because during this period the ethnic group was recorded in more detail than before. Both parents were West Indian in approximately one-tenth of all births, and Indian or Pakistani in one-fortieth. The proportion of children whose parents were both Irish is known only for 1963-65, when it was one-tenth of the total.

Only $2.3 \%$ of all births were of unrecorded or incompletely recorded ethnic origin; but this group included $7 \cdot 1 \%$ of malformed individuals-almost as many as there were in all the non-European and part-European groups combined. In 1963-65 threetenths of the deficient records relating to malformed children lacked information about their fathers only, and seven-tenths gave neither parent's ethnic group. The reason for the high frequency of these deficiencies in malformed children is that many died before they could be documented by a health visitor. The hospital staff and midwives responsible for documentation in such cases did it less thoroughly: the ethnic group was omitted in about seven times as great a proportion of stillbirths and neonatal deaths as of survivors (Table II).

It is essential to consider whether these stillbirths and neonatal deaths of unrecorded origin are likely to have included a substantial excess of immigrants' children; such an excess could seriously bias the results of any comparison of the incidence of lethal malformations in different ethnic groups based on these data. The social class distribution of the stillbirths and neonatal deaths in question is perhaps 
TABLE III STILLBIRTHS AND NEONATAL DEATHS CLASSIFIED ACCORDING TO SOCIAL CLASS 1963-65

\begin{tabular}{|c|c|c|c|c|c|}
\hline \multirow{3}{*}{ Parental Origin } & \multicolumn{5}{|c|}{ Social Class } \\
\hline & \multirow{2}{*}{$\begin{array}{l}\text { I-III } \\
\text { (No.) }\end{array}$} & \multicolumn{2}{|c|}{ IV-V } & \multicolumn{2}{|c|}{ Unrecorded } \\
\hline & & No. & $\begin{array}{c}\% \\
\text { (among cases of } \\
\text { known class) }\end{array}$ & No. & $\begin{array}{c}\% \\
\text { (among } \\
\text { all cases) }\end{array}$ \\
\hline $\begin{array}{l}\text { Both parents recorded } \\
\text { British } \\
\text { Irish } \\
\text { British } \times \text { Irish } \\
\text { Other European } \\
\text { West Indian } \\
\text { European } \times \text { West Indian } \\
\text { Indian or Pakistani } \\
\text { European } \times \text { Indian or Pakistani } \\
\text { Other }\end{array}$ & $\begin{array}{r}869 \\
103 \\
61 \\
28 \\
71 \\
15 \\
29 \\
8 \\
10\end{array}$ & $\begin{array}{r}234 \\
80 \\
51 \\
5 \\
106 \\
9 \\
44 \\
6 \\
6\end{array}$ & $\begin{array}{l}21 \cdot 2 \\
43 \cdot 7 \\
45 \cdot 5 \\
15 \cdot 2 \\
59 \cdot 9 \\
37 \cdot 5 \\
60 \cdot 3 \\
42 \cdot 9 \\
37 \cdot 5\end{array}$ & $\begin{array}{r}63 \\
6 \\
7 \\
4 \\
30 \\
5 \\
4 \\
2 \\
1\end{array}$ & $\begin{array}{r}5 \cdot 4 \\
3 \cdot 2 \\
5 \cdot 9 \\
10 \cdot 8 \\
14 \cdot 5 \\
17 \cdot 2 \\
5 \cdot 2 \\
12 \cdot 5 \\
5 \cdot 9\end{array}$ \\
\hline $\begin{array}{l}\text { Mother alone recorded } \\
\text { Mother not recorded }\end{array}$ & $\begin{array}{r}25 \\
125\end{array}$ & $\begin{array}{l}24 \\
38\end{array}$ & $\begin{array}{l}49 \cdot 0 \\
23 \cdot 3\end{array}$ & $\begin{array}{l}40 \\
70\end{array}$ & $\begin{array}{l}44 \cdot 9 \\
30 \cdot 0\end{array}$ \\
\hline Total & 1,344 & 603 & $31 \cdot 0$ & 232 & $10 \cdot 6$ \\
\hline
\end{tabular}

the best available guide to their parentage, in view of the concentration of immigrants in the poorer classes (Table III). The proportion of children allocated to classes IV and V (31\% of all stillbirths and neonatal deaths of known social background) was significantly higher $(49 \%)$ among those whose fathers' origins alone were omitted, and lower $(23 \%)$ among those of unrecorded maternal origin. These findings are open to criticism on the ground that a high proportion of the children whose ethnic groups were omitted were of unrecorded social class; but they are supported by the following other reasons for thinking that the proportion of children whose parents were immigrants was relatively high in the group for whom information was only lacking in respect of the father, and low in the group whose mothers' origins were not given:

(i) Among the 89 children whose fathers' origins alone were omitted, the percentage with immigrant mothers was $8 \%$ higher than among those whose parents' origins were both recorded (Table IV). Probably in most of these 89 cases the reason for the attendant at the birth not recording the paternal

TABLE IV

STILLBIRTHS AND NEONATAL DEATHS WHOSE MOTHERS' ETHNIC ORIGINS WERE RECORDED 1963-65

\begin{tabular}{|c|c|c|c|c|}
\hline \multirow[t]{2}{*}{ Origin of Mother } & \multicolumn{2}{|c|}{$\begin{array}{c}\text { Father's Origin } \\
\text { Recorded }\end{array}$} & \multicolumn{2}{|c|}{$\begin{array}{l}\text { Father's Origin } \\
\text { not Recorded }\end{array}$} \\
\hline & No. & $\%$ & No. & $\%$ \\
\hline $\begin{array}{l}\text { Great Britain } \\
\text { Ireland } \\
\text { Rest of Europe } \\
\text { West Indies } \\
\text { India or Pakistan } \\
\text { Rest of world }\end{array}$ & $\begin{array}{r}1,304 \\
238 \\
18 \\
207 \\
77 \\
13\end{array}$ & $\begin{array}{r}70 \cdot 2 \\
12 \cdot 8 \\
1 \cdot 0 \\
11 \cdot 1 \\
4 \cdot 1 \\
0 \cdot 7\end{array}$ & $\begin{array}{l}55 \\
18 \\
1 \\
14 \\
1 \\
-\end{array}$ & $\begin{array}{r}61 \cdot 8 \\
20 \cdot 2 \\
1 \cdot 1 \\
15 \cdot 7 \\
1 \cdot 1 \\
-\end{array}$ \\
\hline$\overline{\text { Total }}$ & 1,857 & 100 & $89^{\circ}$ & 100 \\
\hline
\end{tabular}

origin was reluctance or inability to obtain this information-difficulties which may be especially likely to arise in cases with immigrant fathers.

(ii) Most of the omissions involving maternal origin, on the other hand, are likely to have been inadvertent, since the attendant must almost always have this information. The tendency for such omissions to be rarest in the poorer classes where? immigrants are concentrated has been noted in relation to other items in the Birmingham Health Department birth records (Leck, 1961) as well as ethnic group.

In 1963-65 stillbirths and neonatal deaths of unrecorded maternal ethnic group were more than twice as numerous as those -whose fathers' origins alone were omitted, with the result that among all those whose ethnic origins were not fully recorded (the two groups combined) the proportion in social classes IV and V was rather lower than among those of known ethnic group - the reverse of the pattern to be expected if those with incomplete records included an excess of immigrants. It therefore seems reasonable to use the figures for children of known origin to compare the incidence of malformations in the different ethnic groups.

The frequency of the specific types of defects considered is shown in Table $\mathrm{V}$ for all births in 1960-65 and births to European parents in 1963-65, classified according to ethnic group. Incidence in the three main immigrant groups is compared with the pattern in other Birmingham births in Table VI, and with figures for some ethnically related populations in other countries in Table VII. As these other populations were all collected in maternity hospitals they may not be entirely representative of all births, and some cases of Down's disease, oesophageal 
TABLE V

ETHNIC DISTRIBUTION OF SELECTED MALFORMATIONS AMONG BIRTHS TO BIRMINGHAM RESIDENTS $1960-65$

\begin{tabular}{|c|c|c|c|c|c|c|c|c|c|c|c|c|c|c|c|c|}
\hline \multirow{2}{*}{$\begin{array}{l}\text { Year of birth } \\
\text { Parental origin }\end{array}$} & & \multirow{2}{*}{$\begin{array}{l}\cdots \\
\cdots\end{array}$} & \multirow{2}{*}{$\begin{array}{l}\cdots \\
\cdots\end{array}$} & \multirow{2}{*}{$\begin{array}{l}\cdots \\
\cdots\end{array}$} & \multicolumn{7}{|c|}{ All Years } & \multicolumn{5}{|c|}{$1963-65$} \\
\hline & & & & & 害哭 & 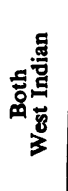 & 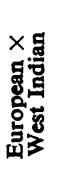 & 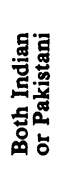 & 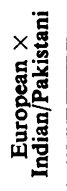 &  & z: & 点: & 㔚告 & 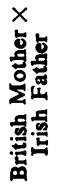 &  & 害最 \\
\hline \multicolumn{5}{|c|}{$\begin{array}{l}\text { Anencephalus--with rhachischisis } \\
\text { without rhachischisis } \\
\text { Spina bifida aperta } \\
\text { Encephalocele }\end{array}$} & $\begin{array}{r}44 \\
136 \\
222 \\
51\end{array}$ & $\begin{array}{l}0 \\
6 \\
7 \\
1\end{array}$ & $\begin{array}{l}0 \\
2 \\
2 \\
1\end{array}$ & $\begin{array}{l}2 \\
6 \\
6 \\
3\end{array}$ & $\begin{array}{l}0 \\
\mathbf{1} \\
\mathbf{3} \\
\mathbf{0}\end{array}$ & $\begin{array}{l}\mathbf{0} \\
\mathbf{0} \\
\mathbf{0} \\
\mathbf{0}\end{array}$ & $\begin{array}{r}10 \\
32 \\
19 \\
2\end{array}$ & $\begin{array}{l}13 \\
46 \\
80 \\
11\end{array}$ & $\begin{array}{r}2 \\
11 \\
23 \\
4\end{array}$ & $\begin{array}{l}1 \\
2 \\
4 \\
1\end{array}$ & $\begin{array}{l}\mathbf{0} \\
1 \\
0 \\
0\end{array}$ & $\begin{array}{l}\mathbf{0} \\
\mathbf{2} \\
\mathbf{0} \\
\mathbf{0}\end{array}$ \\
\hline \multicolumn{5}{|c|}{ Total children with neural tube defects } & 446 & 14 & 5 & 17 & 4 & $\mathbf{0}$ & 63 & 150 & 40 & 8 & 1 & 2 \\
\hline \multicolumn{5}{|c|}{$\begin{array}{l}\text { Cleft palate } \\
\text { Cleft lip } \\
\text { Cleft palate with cleft lip }\end{array}$} & $\begin{array}{l}69 \\
45 \\
94\end{array}$ & $\begin{array}{l}3 \\
2 \\
3\end{array}$ & $\begin{array}{l}1 \\
1 \\
0\end{array}$ & $\begin{array}{l}\mathbf{1} \\
\mathbf{0} \\
\mathbf{3}\end{array}$ & $\begin{array}{l}0 \\
0 \\
1\end{array}$ & $\begin{array}{l}\mathbf{0} \\
\mathbf{0} \\
\mathbf{0}\end{array}$ & $\begin{array}{l}0 \\
2 \\
2\end{array}$ & $\begin{array}{l}29 \\
18 \\
31\end{array}$ & $\begin{array}{l}5 \\
2 \\
2\end{array}$ & $\begin{array}{l}\mathbf{0} \\
\mathbf{0} \\
\mathbf{3}\end{array}$ & $\begin{array}{l}\mathbf{0} \\
1 \\
0\end{array}$ & $\begin{array}{l}1 \\
0 \\
1\end{array}$ \\
\hline \multicolumn{5}{|c|}{ Total children with oral clefts } & 208 & 8 & 2 & 4 & 1 & $\mathbf{0}$ & 4 & 78 & 9 & 3 & 1 & 2 \\
\hline \multicolumn{5}{|l|}{ Down's disease } & 187 & 11 & 2 & 4 & 1 & 2 & 2 & 68 & 17 & 6 & 3 & 4 \\
\hline \multicolumn{5}{|c|}{$\begin{array}{l}\text { Oesophageal atresia/fistula } \\
\text { Atresia of rectum/anal canal } \\
\text { Bilateral renal agenesis } \\
\text { Reduction deformities of limbs } \\
\text { Diaphragmatic hernia (not hiatal) } \\
\text { Exomphalos }\end{array}$} & $\begin{array}{l}39 \\
53 \\
12 \\
60 \\
45 \\
39\end{array}$ & $\begin{array}{l}1 \\
3 \\
2 \\
8 \\
2 \\
3\end{array}$ & $\begin{array}{l}\mathbf{0} \\
\mathbf{0} \\
\mathbf{0} \\
\mathbf{0} \\
1 \\
\mathbf{0}\end{array}$ & $\begin{array}{l}0 \\
2 \\
0 \\
1 \\
1 \\
0\end{array}$ & $\begin{array}{l}\mathbf{0} \\
\mathbf{0} \\
\mathbf{0} \\
\mathbf{0} \\
\mathbf{0} \\
\mathbf{0}\end{array}$ & $\begin{array}{l}1 \\
0 \\
1 \\
0 \\
0 \\
0\end{array}$ & $\begin{array}{l}2 \\
5 \\
8 \\
4 \\
7 \\
5\end{array}$ & $\begin{array}{r}16 \\
22 \\
4 \\
21 \\
10 \\
9\end{array}$ & $\begin{array}{l}1 \\
5 \\
0 \\
3 \\
1 \\
1\end{array}$ & $\begin{array}{l}2 \\
1 \\
0 \\
2 \\
1 \\
0\end{array}$ & $\begin{array}{l}0 \\
1 \\
0 \\
3 \\
0 \\
0\end{array}$ & $\begin{array}{l}\mathbf{0} \\
\mathbf{0} \\
\mathbf{0} \\
\mathbf{0} \\
1 \\
\mathbf{0}\end{array}$ \\
\hline \multicolumn{5}{|c|}{ Total children with miscellaneous defects } & 227 & 18 & 1 & 4 & $\mathbf{0}$ & 2 & 23 & 76 & 11 & 5 & 4 & 1 \\
\hline
\end{tabular}

atresia, renal agenesis, and diaphragmatic hernia are likely to have been missed-Down's disease because the other series were not followed for long enough after birth to ensure the detection of all cases, and the other defects because they may not be found in dead children unless these come to necropsy, which in some series few did. These four defects have therefore been omitted from Table VII although included in Tables V and VI. Children with multiple defects are enumerated once in each applicable category of all three tables.

The most conclusive finding in these tables is that the children of West Indian immigrants to Birmingham are quite unlike the offspring of Europeans there in respect of the incidence of malformations, but they do not differ significantly from negro populations elsewhere. The most striking aspects of the contrast between the two groups in Birmingham were the much lower figures for neural and oral defects in the West Indians. The incidence of Down's disease was also relatively low in this group, and the difference did not appear to be due to the wellknown effect of maternal age on incidence: the ratio of the observed number of children with Down's disease to the number expected (standardized for maternal age*) was 1.06 for Europeans and 0.56 for West Indians.

-Expected numbers are calculated by summing the products obtained when the incidence of affected individuals in each maternal age group of the general population is multiplied by the total number of births of similar maternal age in the ethnic group concerned.
The Birmingham children of Indian and Pakistani descent, on the other hand, differed significantly (although only in respect of neural tube defects) from the other Indian series quoted (from Bombay) but not from the local European population. The incidence of these defects was higher among Indian and Pakistani immigrants to Birmingham but lower in Bombay than in Birmingham children of European descent.

Among Birmingham births to Irish parents, neural tube defects were significantly more common than in those of British origin, but significantly less common than in Belfast, Northern Ireland.

\section{Discussion}

Opinions differ on whether the variability of the incidence of malformations between ethnic groups is due mainly to differences in the environment (Morton, 1962) or in the population frequency of particular combinations of the genes that influence development (Neel, 1958). In the present series, the findings among immigrants from Ireland and from India and Pakistan are compatible with either hypothesis, but the contrast between the European and West Indian figures seems likely to be genetic in origin.

The British, Irish, and Indian or Pakistani populations differed mainly in respect of neural tube defects, and even more extreme differences of this kind between caucasoid communities have been described by Penrose (1957), Neel (1958), and 
TABLE VI

INCIDENCE OF AFFECTED INDIVIDUALS (PER 1,000 TOTAL BIRTHS) IN MAIN ETHNIC GROUPS IN BIRMINGHAM

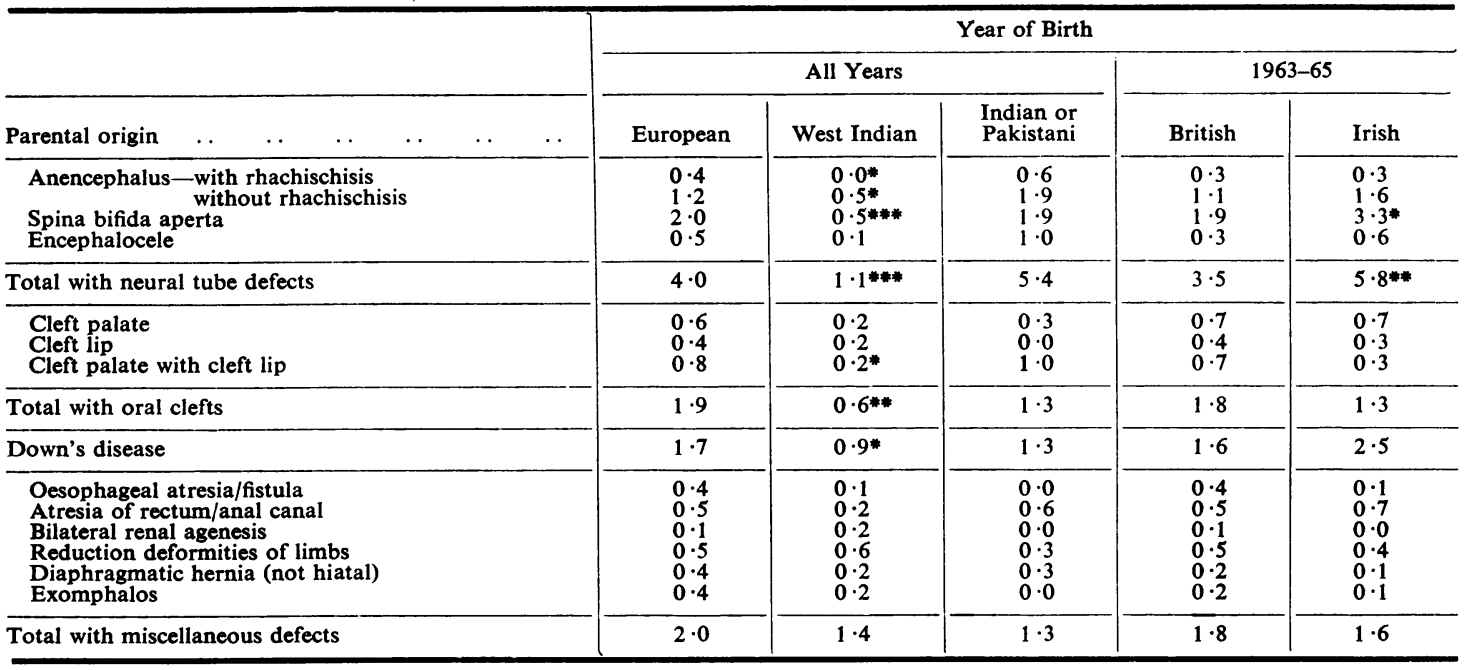

- Immigrant values differing significantly (at the $0.05,0.01$, and 0.001 levels respectively) from the European or British figures for


correction in all other cases.

TABLE VII

INCIDENCE OF AFFECTED INDIVIDUALS (PER 1000 TOTAL BIRTHS) AMONG IMMIGRANT GROUPS IN BIRMINGHAM AND ETHNICALLY RELATED POPULATIONS ELSEWHERE

\begin{tabular}{|c|c|c|c|c|c|c|c|c|c|}
\hline \multirow[b]{3}{*}{ Locality } & \multicolumn{9}{|c|}{ Parental Origin } \\
\hline & \multicolumn{2}{|c|}{ Irish } & \multicolumn{2}{|c|}{ Indian or Pakistani } & \multicolumn{5}{|c|}{ Negroid } \\
\hline & $\underset{\substack{\text { ham } \\
(6,880)}}{\text { Birming- }}$ & $\begin{array}{l}\text { Belfast }^{1} \\
(29,202)\end{array}$ & $\begin{array}{c}\text { Birming- } \\
\text { ham } \\
(3,132)\end{array}$ & $\begin{array}{c}\text { Bombay }^{1} \\
(40,493)\end{array}$ & \begin{tabular}{|c|} 
Birming- \\
ham (West \\
Indian) \\
$(12,756)$
\end{tabular} & $\underset{(10,425)}{\text { Pretoria }^{1}}$ & $\begin{array}{l}\text { Panama \& } \\
\text { São Paulo' } \\
\quad(3,733)\end{array}$ & $\begin{array}{c}\text { New York } \\
\text { City }{ }^{2} \\
(\text { ca. } 4,300)\end{array}$ & $\begin{array}{c}14 \text { U.S.A. } \\
\text { Cities }^{3} \\
(16,959)\end{array}$ \\
\hline $\begin{array}{l}\text { Anencephalus } \\
\text { with rachischisis } \\
\text { without rachischisis } \\
\text { Spina bifida aperta } \\
\text { Encephalocele }\end{array}$ & $\begin{array}{l}0 \cdot 3 \\
1.6 \\
3 \cdot 3 \\
0.6\end{array}$ & $\begin{array}{l}0 \cdot 3 \\
4 \cdot 1 * * \\
4 \cdot 0 \\
0 \cdot 2\end{array}$ & $\begin{array}{l}0 \cdot 6 \\
1.9 \\
1.9 \\
1.0\end{array}$ & $\begin{array}{l}0 \cdot 1 \\
1 \cdot 5 \\
1 \cdot 1 \\
0 \cdot 1\end{array}$ & $\begin{array}{l}0 \cdot 0 \\
0 \cdot 5 \\
0 \cdot 5 \\
0 \cdot 1\end{array}$ & $\begin{array}{l}0 \cdot 1 \\
0 \cdot 4 \\
1 \cdot 1 \\
0 \cdot 0\end{array}$ & $\begin{array}{l}0 \cdot 3 \\
0 \cdot 3 \\
0 \cdot 5 \\
0 \cdot 3\end{array}$ & $\begin{array}{c}0 \cdot 2 \\
1 \cdot 1 \\
?\end{array}$ & $\begin{array}{r}0.4 \\
0.5\end{array}$ \\
\hline Total with neural tube defects & $5 \cdot 8$ & $8 \cdot 7 *$ & $5 \cdot 4$ & $2 \cdot 8 *$ & $1 \cdot 1$ & $1 \cdot 6$ & $1 \cdot 3$ & $?$ & 0.9 \\
\hline $\begin{array}{l}\text { Cleft palate } \\
\text { Cleft lip } \\
\text { Cleft palate with cleft lip }\end{array}$ & $\begin{array}{l}0 \cdot 7 \\
0 \cdot 3 \\
0 \cdot 3\end{array}$ & $\begin{array}{l}0 \cdot 7 \\
0 \cdot 4 \\
0 \cdot 7\end{array}$ & $\begin{array}{l}0 \cdot 3 \\
0 \cdot 0 \\
1 \cdot 0\end{array}$ & $\begin{array}{l}0.1 \\
0.4 \\
0.9\end{array}$ & $\begin{array}{l}0 \cdot 2 \\
0 \cdot 2 \\
0 \cdot 2\end{array}$ & $\begin{array}{l}0 \cdot 4 \\
0 \cdot 2 \\
0.0\end{array}$ & $\begin{array}{l}0 \cdot 3 \\
0 \cdot 3 \\
0 \cdot 3\end{array}$ & $\begin{array}{l}0 \cdot 2 \\
0 \cdot 7\end{array}$ & $\begin{array}{l}0.4 \\
0.4\end{array}$ \\
\hline Total with oral clefts & $1 \cdot 3$ & $1 \cdot 7$ & $1 \cdot 3$ & $1 \cdot 5$ & 0.6 & 0.6 & $0 \cdot 8$ & $1 \cdot 0$ & $0 \cdot 8$ \\
\hline $\begin{array}{l}\text { Atresia of rectum/anal } \\
\text { canal } \\
\text { Reduction deformities of } \\
\text { limbs } \\
\text { Exomphalos }\end{array}$ & $\begin{array}{l}0.7 \\
0.4 \\
0.1\end{array}$ & $\begin{array}{l}0 \cdot 2 \\
0 \cdot 2 \\
0 \cdot 1\end{array}$ & $\begin{array}{l}0.6 \\
0.3 \\
0.0\end{array}$ & $\begin{array}{l}0 \cdot 4 \\
0 \cdot 4 \\
0 \cdot 3\end{array}$ & $\begin{array}{l}0 \cdot 2 \\
0 \cdot 6 \\
0 \cdot 2\end{array}$ & $\begin{array}{l}0 \cdot 2 \\
0 \cdot 1 \\
0 \cdot 1\end{array}$ & $\begin{array}{l}0 \cdot 3 \\
0 \cdot 5 \\
0 \cdot 3\end{array}$ & $\begin{array}{l}? \\
?\end{array}$ & $\begin{array}{l}? \\
?\end{array}$ \\
\hline $\begin{array}{l}\text { Total with miscellaneous } \\
\text { defects }\end{array}$ & $1 \cdot 3$ & $0 \cdot 5$ & $1 \cdot 0$ & $1 \cdot 1$ & $1 \cdot 1$ & 0.4 & $1 \cdot 1$ & $?$ & $?$ \\
\hline
\end{tabular}

1 Stevenson, Johnston, Golding and Stewart (1966). The total given for the Panama and São Paulo population is an estimate, calculated from the published data on the assumption that all multiple births were twins. Mellin (1963)

3 Chung and Myrianthopoulos (1968).

- Values from other series differing significantly (at the 0.05-0.01 and 0.01-0.001 levels respectively) from the Birmingham figures for - - the same ethnic group. Significance was estimated as in Table VI. 
Stevenson, Johnston, Stewart, and Golding (1966). In the Irish and Indian or Pakistani groups in Birmingham, incidence was closer to the figures for the rest of the local population (Table VI) than to those reported from Belfast and Bombay respectively (Table VII). The main difficulty about accepting this pattern as a reflection of environmental differences between localities is that the Belfast and Bombay figures may not be typical of the communities from which the immigrants came. The Belfast figure for neural tube defects $(8 \cdot 7 / 1000)$ was elevated by the exclusion of domiciliary births (Stevenson et al., 1966), and the Annual Reports for 1964-66 of the Registrar-General for Northern Ireland record only 7.5 cases/1000 total births, not significantly more than in Birmingham children of Irish origin. The difference between the two groups of Indian or Pakistani origin may only indicate that the immigrants came from areas of higher incidence than Bombay; many of them are Sikhs, among whom it appears from data from the Punjab that these defects are especially common (Stevenson et al., 1966). There is, however, independent evidence from Boston, Mass. (Naggan and MacMahon, 1967) and Hawaii (Morton, Chung and Mi, 1967) that the incidence of neural tube defects in the descendants of caucasoid migrants may tend to move away from the pattern observed in their country of origin and toward that shown by the rest of the local population.
The similarity of the incidence of malformations in West Indians to the pattern in North and South American negroes and in the South African Bantu (Table VII), and the sharp contrast between these and the European figures for neural and oral defects (Table VI), seem to invite a genetic explanation. As far as anencephalus and cleft lip are concerned, the contrast is as marked in cities of the United States of America as in Birmingham (Figure), although the North American negroes studied had been in a non-tropical industrialized environment for much longer on average than the West Indian immigrants to England. There was no such contrast between the Birmingham figures for Europeans and those for children of Indian or Pakistani parents, who genetically are much closer to the indigenous community than the West Indians but differ more culturally.

If it is accepted that the contrast in incidence between caucasoid and negroid populations is probably due mainly to differences in the frequency of certain combinations of genes, the nature of these combinations must be considered. Neel (1958) suggested that a high level of homozygosity in the genotype as a whole might predispose to malformations, and that the low incidence of defects in North American negroes might reflect the reduction in homozygosity occasioned by their mixed descent. The additional data now available do not support this suggestion. The proportion of children with



FIGURE.-Incidence of certain malformations in caucasoid and negroid children. 
neural or oral defects was at least as small among the offspring of West Indian immigrants as among the North American negroes, although the immigrants appear from blood group data (Leck, 1969) to be of less mixed descent; and the proportion affected was even lower in the small series reported by Simpkiss and Lowe (1961) from Uganda, where miscegenation has been negligible.

It therefore seems possible that all negroid populations differ from caucasoids in the respects described, which suggests that this contrast may be secondary to the well-recognized genetically determined morphological differences between these ethnic groups. Even if these differences were only slight during embryonic life, they might well produce contrasts in the incidence of malformations as great as those described. For example, if a certain malformation occurred whenever the value of a particular normally distributed developmental variable exceeded a certain threshold, the mean values of the variable for two populations would only need to differ by about one-fifth of a standard deviation for the defect to occur in two per 1000 of one population and one per 1000 of the other (Leck, 1965). Genetically determined ethnic differences at least as great are shown by the mean values of many morphological variables. Such variables can of course also be influenced by environmental factors, which, as Carter (1964) has suggested, must often determine finally whether the threshold beyond which malformation occurs is exceeded in an individual whose genotype puts him near to such a threshold. It seems that both the environmental and the genetic components in this process may vary according to ethnic group.

\section{SUMMARY}

The incidence of substantial malformations, mostly of types readily ascertained at birth, was studied in a series of 133,539 Birmingham children (including stillbirths) born in 1960-65, who were classified according to ethnic group. In children of European, Indian, or Pakistani parentage, anencephalus, spina bifida, and clefts of the lip and palate were much commoner than in those of West Indian origin, among whom incidence was approximately the "same as in published series of American and African negroes. The children of migrants from Ireland and from India and Pakistan differed siknificantly from populations previously studied in their countries of origin, and resembled more closely the rest of the Birmingham population, in respect of the incidence of neural tube defects.

It is concluded that environmental influences may contribute to the variations in incidence observed among caucasoid populations, but that the much greater contrast between negroid and caucasoid children is probably due mainly to genetic differences.

Particulars of Birmingham children were made available by Dr. E. L. M. Millar (Medical Officer of Health), Sir Lionel Russell (Chief Education Officer) and their staffs, and by the medical staff and statistical and records officers of local hospitals. Mrs. Eileen Armstrong, Mrs. Gillian Bowater, Miss Ida Giles, and Mrs. Betty Mann helped to assemble these data. The figure was drawn by Mrs. Juliet Bebbington. I am grateful to all these people for their ready co-operation, and to the Wates Foundation for financial support.

\section{REFERENCES}

Carter, C. O. (1964). The genetics of common malformations. In Second International Conference on Congenital Malformations, New York, 1963. Ed. Fishbein, M. Pp. 306-313. International Medical Congress, New York.

Charles, E. (1951). Statistical utilization of maternity and child welfare records. Brit. J. soc. Med., 5,41 .

Chung, C. S., and Myrianthopoulos, N. C. (1968). Racial and prenatal factors in major congenital malformations. Amer. J. hum. Genet., $20,44$.

Computation Laboratory of Harvard University (1955) Tables of the Cumulative Binomial Probability Distrio bution. Annals of the Computation Laboratory of Harvard University, 35. Harvard University Press, Cambridge, Mass.

EDWARDS, J. H., LeCK, I., and ReCORD, R. G. (1964). A classification of malformations. Acta genet. (Basel), 14, 76.

LECK, I. (1961). Malformations in a population observed for five years after birth. Ph.D. Thesis, University of Birmingham.

(1964). Examination of the incidence of malforma tions for evidence of drug teratogenesis. Brit. J. prev soc. Med., 18, 196.

- (1965). Current concepts: etiology of malformations. New Engl. J. Med., 273, 864.

- (1966). Incidence and epidemicity of Down's syndrome. Lancet, $2,457$.

- (1969). A note on the blood groups of Commonwealth immigrants to England. Brit. J. prev. soc. Med., 23, 163.

$\longrightarrow$, and MillaR, E. L. M. (1963). Short-term changes in the incidence of malformations. Ibid., $17,1$.

- Record, R. G., McKeown, T., and Edwards, J. H. (1968). The incidence of malformations in Birmingham, England, 1950-1959. Teratology, 1, 263.

Mellin, G. W. (1963). The frequency of birth defects. In Birth Defects. Ed. Fishbein, M. Pp. 1-17. Lippincott, Philadelphia.

MORTON, N. E. (1962). Genetics of inter-racial crosses in Hawaii. Eugen. Quart., 9, 23.

- Chung, C. S., and MI, M.-P. (1967) Genetics of inter-racial crosses in Hawaii. Monogr. hum. Genet., 3. Karger, Basel. 
NAGgaN, L., and MacMaHon, B. (1967). Ethnic differences in the prevalence of anencephaly and spina bifida in Boston, Massachusetts. New Engl. J. Med., $277,1119$.

NeEL, J. V. (1958). A study of major congenital defects in Japanese infants. Amer. J. hum. Genet., 10, 398.

PenRose, L. S. (1957). Genetics of anencephaly. J. ment. Defic. Res., $1,4$.

SimpKISS, M., and Lowe, A. (1961). Congenital abnormalities in the African newborn. Arch. Dis. Childh., 36, 404.
Stevenson, A. C., Johnston, H. A., Golding, D. R., and STEWART, M. I. P. (1966). World Health Organization Comparative Study of Congenital Malformations: Basic Tabulations in respect of Consecutive Post 28-Week Births recorded in the Co-operating Centres. Medical Research Council Population Genetics Research Unit, Oxford.

- - - Stewart, M. I. P., and Golding, D. R. (1966). Congenital Malformations. A Report of a Study of Series of Consecutive Births in 24 Centres. Bull. Wld. Hlth. Org., 34, Suppl. 